\title{
A study of Radon Concentration in Homes in the Sea to Sky Corridor and the North Shore of Vancouver British Columbia
}

Misha Lu', Dale Chen², Anne Marie Nicol ${ }^{3}$

1. Lead Author, B. Tech Student, School of Health Sciences, British Columbia Institute of Technology, 3700 Willingdon Ave, Burnaby, BC V5G 3H2

2. Supervisor, School of Health Sciences, British Columbia Institute of Technology, 3700 Willingdon Ave, Burnaby, BC V5G 3H2

3. Associate Professor, Faculity of Health Sciences, Simon Fraser University, 8888 University Drive, Burnaby, BC V5A 156

\begin{abstract}
Background: Radon is odourless and colourless gas. It is the second leading cause of lung cancer and can only be found through testing. A radon potential map released in 2012 and highlighted various areas of British Columbia which were high in radon. This study focused on testing for radon gas in houses within the Sea to Sky Corridor and North Shore, areas noted to be high in radon.
\end{abstract}

Methods: This study was conducted by reaching out to participants who lived within these areas. Radon test kits were distributed, and patrons were instructed to keep these kits on the lowest level of the home for at least 91 days. After the 91-day period, the radon test kits were collected and sent to a lab for further results.

Results: The lab results were analysed with NCSS Data Analysis software. Three statistical tests were conducted looking at the different areas, types of foundation and if the houses tested are below the recommended average. Two of the two sample T tests were not significant, and the one sample $T$ test came back significant.

Conclusion: The two-sample t test (comparison against the two areas) showed that radon did not have equal concentrations. The same can be said with the two sample t tests 
against foundation types (slab on grade and crawl space). All samples were then compared against the recommend limit set by Health Canada $\left(200 \mathrm{~Bq} /{ }^{3}\right)$, and was concluded that they were all below this limit.

Key Words: Radon, Radon Gas, Vancouver, Sea to Sky, North Shore 


\section{INTRODUCTION}

Exposure to radon is ubiquitous. It is found in the air, the soil, and in building materials such as brick and concrete (WHO, 1944). For public health concerns there seem to be no short-term health complications with radon exposure, however, this is not the case for long term exposure. It is believed that about $10 \%$ of all lung cancers deaths are radon related (WHO, 1944). With the guidance from Dr. Anne-Marie Nicol, a researcher from Simon Fraser University, the rationale for this study is to determine radon levels in homes on Vancouver's north shore, and sea to sky corridor.

Radon is measured in becquerels $(\mathrm{Bq})$, and it is the amount of material that produces one nuclear disintegration per second (Copes and Scott, 2007). Many countries, including Canada, have attempted to act on the indoor radon gas issue at large. For instance, the United Sates has a strict guideline of $150 \mathrm{~Bq} / \mathrm{m}^{3}$ (Copes and Scott, 2007). Canada's guide line has lowered the exposure from 800

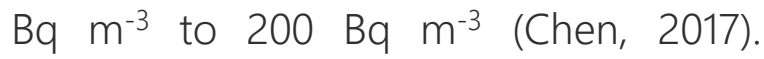
Currently, the Canadian government is encouraging home owners to take action and reduce radon exposure (Chen, 2017).. Although there are many regulations in place to reduce radon in homes, it is still affecting many people worldwide.

\section{LITERATURE REVIEW}

\section{What is Radon}

Radon is an element found in earth's crust. Radon itself is a gas, odorless and colorless, therefore is it not easy to detect or notice inside a home dwelling (Barnes et al., 2010). Radon-222 is the product of decay from Uranium238 and it has a half-life of four days (Derby et al., 2005). There are two isotopes of Radon; Radon - 222 and Radon - 220, however, this study will look at $\mathrm{Rn}-222$ (WHO, 1988). When Rn-222 decays, it passes through the soil and into the air. It then produces radioactive progeny, Polonium - 218 and Polonium 214. These progeny are solid, and when inhaled stay within the bronchial epithelium thus exposing cells to alpha irritation days (Derby et al., 2005). Although one's exposure to Radon might 
be low, the prolonged exposure to it can cause chronic disease, such as cancer, because of the low but constant exposure to alpha radiation.

\section{Radon and Location}

The detection of radon has been done in various places such as; banks, places of education, office spaces, retail and healthcare to list a few (Gooding, 2018). The location of radon testing is usually determined by several key pieces of data. Factors to determine a radon zone include; geology, soil parameters, foundation types and radioactivity (Jones, Foster and Bernes, 2018). In addition to the previously mentioned factors, the basement of homes are common radon testing locations (Cucos Dinu et al., 2012). Cellars tend to have the highest radon concentrations because radon is heavier than air (Cucos Dinu et al., 2012).. Therefore, placing radon testing kits in basements is beneficial to obtaining results.

Radon levels varies in every region of Canada, but it is very much present on Canadian soil. New Brunswick, Manitoba, Saskatchewan and Yukon territory all have about $15.0 \%$ of people living in homes with radon concentrations greater than 200 Bq/m3 (Statistics Canada, 2016). In British Columbia there are about 5.0\% of people living in homes with radon concentrations greater than $200 \mathrm{~Bq} / \mathrm{m} 3$ (Statistics Canada, 2016). Figure 1 is a radon map done on the lower mainland (Vancouver, British Columbia) where the data where dark red indicates zone 1 (high), red indication zone 2 (elevated) and pink indicating zone 3 (guarded). Our area of interest (North Vancouver) is in zone 3. (Radon Environmental Management Corp., 2012).

Lower Mainland inset

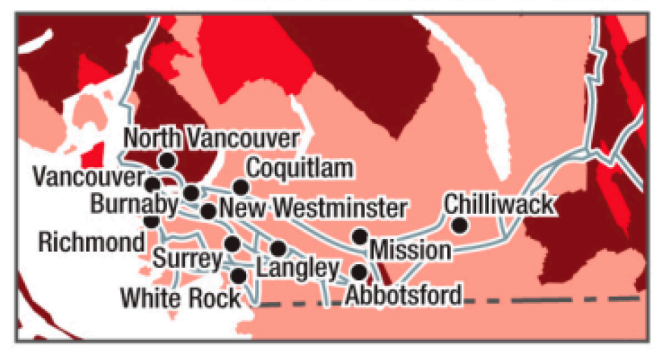

Figure 1: Radon map image of the lower main land obtained from Radon Environmental 2012.

\section{Radon in Homes and Factors that Influence Radon in Homes}

The accumulation of radon inside homes is a problem because it can effect 
a large number of people causing lung cancer (Darby et al., 2005). Radon's gaseous state allows it to enter and collect in the basement of homes, not so much by diffusion but by a pressure driven flow (WHO, 1988). The inflow of radon is determined by the difference between soil and indoor air (WHO, 1988). Radon collects in the bottom of the home because radon gas comes from the surrounding soil. However, many other factors can determine radon in houses such as climate, soil, building material and ventilation to list a few (Baeza, GarcíaPaniagua, Guillén, \& Montalbán, 2018).

\section{a. Building Foundation and Soil}

One aspect to determining radon exposure is to look at the building foundation and soil type a house was built on. Houses built on a underlaying rock like granite, gneisses or metamorphic rocks are at risk for higher radon exposure because uranium is typically associated with these rocks (Hauri, Huss, Zimmermann, Kuehni, \& Röösli, 2012; Kropat et al., 2014). Soil is the main source of radon and it is the medium which should not be overlooked, as radon moves through it before being released into the air (Collignan, Lorkowski, \& Améon, 2012). Along with texture, soil permeability is also affected by geologic faults, degree of inline and elevation above sea level (Hauri et al., 2012).

\section{b. Building Materials}

Radon can also make its way into the house via the material itself (Barnes et al., 2010). One surface material shown to exhaust radon are granites and the use of them for interior decorating purposes (Chen, Rahman, \& Atiya, 2010). Other building materials considered to exhaust radon were drywall and tiles. In a study done with Chen, Rahman, and Atiya (2010), they revealed that radon was found in drywall, tile and granite. However, it was concluded that if a house had adequate air exchange, there were no significant additions to radon inside a home.

\section{c. Weather and Season}

The length of a study can cause variation in radon concentration. Average length of radon testing is 12 months, however shorter time periods can range from 3 to 6 months (Bochicchio et al., 
2005). The length of this study will run from November 2018 to January 2019, which is exactly three months. A study done from July to September, which is three months, was seen to have no seasonal variation (Inoue et al., 2013). This might have been because in these months people tend to open more windows and doors, thus keeping the house well ventilated. It was seen that radon concentration was higher in the winter than the summer (Bochicchio et al., 2005). In the winter months people tend to keep windows and doors closed, making the house less ventilated and therefore letting radon gas accumulate more inside the home. Therefore, the reading from the radon levels could be more accurate because there is no natural ventilation occurring.

\section{Conclusion}

The purpose of this study is to see if there is a difference in radon accumulation from the Lynn Valley Housing Co Op and houses on Draycott road on the north shore. This is a pilot study to determine if there is radon present in the North Vancouver area.

\section{METHODS AND MATERIAL}

This pilot study with Simon Fraser Citizen Science Project and British Columbia Institute of Technology looks at radon gas levels in two areas of Vancouver; the North Shore and the Sea to Sky corridor. A total of 134 homes were tested from the two locations (Table 1).

Table 1: Sample sizes of the North Shore and Sea to Sky Corridor

\begin{tabular}{|c|c|}
\hline District & Sample Size \\
\hline North Shore & 93 \\
\hline Sea to Sky \\
corridor
\end{tabular}

Data was obtained from the previous year from the months of January to May. Special ethical clearance was given by SFU for this project.

\section{Materials}


A Radtrak2 Long Term Radon measurement kit was purchased online from Radonova. The samples were then sent to the Radonova lab where proper procedures were used to analyze the data.

\section{Methods}

Radon samples were collected from various houses on the North Shore and Sea to Sky corridor. Several methods of contact (presentations, news articles, word of mouth, and volunteers) were used to find people interested in the project. Most were done by approach of the people who have heard about Citizen Science. Upon contact, participants were given the following instructions on the radon kit; on where to put it, the sample time collection period and what to do with the packaging.

Location: Participants were instructed to place the kit in the lowest part of the house or basement if they had one in the area where they spent the most time. This was because we were most interested to see the radon levels in areas people would be affected the most. Keeping the doors and windows closed gave the highest reading possible and therefore the most accurate exposure.

Length of Time: For this study, residents were asked to keep the Radtrack2 for at a minimum of three months (Radonova., nd). The length of this study was chosen because of the season. During the winter/ colder months, people tend to keep windows and doors closed and this would let us measure the highest amount of radon in the dwelling.

Packaging. The radon kit is packaged inside an air tight, radon free plastic wrapping. Once opened the test kit will be exposed to air. The kit must be taken out of the packing and placed in the owner's choice spot. Finally, the packaging was properly discarded.

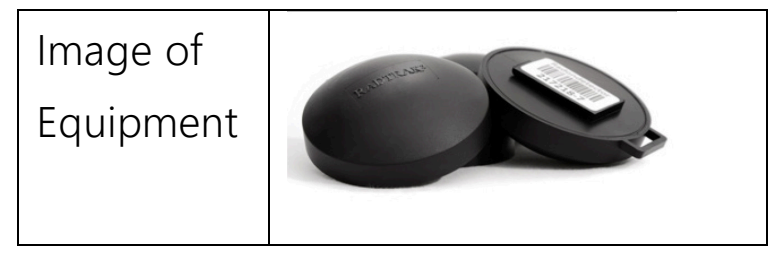




\begin{tabular}{|l|l|}
\hline $\begin{array}{l}\text { Location of } \\
\text { Study }\end{array}$ & $\begin{array}{l}\text { Location \#1 - North } \\
\text { Shore Vancouver } \\
\text { Location \#2 - Sea to Sky } \\
\text { corridor }\end{array}$ \\
\hline Set Up & $\begin{array}{r}\text { 1. } \\
\text { Remove from } \\
\text { packaging } \\
\text { 2. }\end{array}$ \\
& $\begin{array}{l}\text { Place in desired } \\
\text { lived in area) } \\
\text { 3. Collection occurs } \\
\text { for at least three } \\
\text { months } \\
\text { 4. Send into lab and } \\
\text { wait for report }\end{array}$ \\
\hline
\end{tabular}

RESULTS

General Hypothesis

\#1: Two Sample T Test (North Shore and Sea to Sky (orridor):

$H_{0}$ : Radon concentration is equal on the areas of the North Shore and Sea to sky corridor

$\mathrm{H}_{\mathrm{A}}$ : Radon concentration is not equal on the area of the North Shore and Sea to Sky Corridor
\#2: Two Sample T Test (Crawl Space and Slab on grade)

$H_{0}$ : Radon concentration is equal for crawl space and slab on grade foundation types

$\mathrm{H}_{\mathrm{A}}$ : Radon concentration is not equal for crawl space and slab on grade foundation types

\#3: One sample T Test

$\mathrm{H}_{\mathrm{o}}$ : Mean radon concentration levels is greater than $200 \mathrm{~Bq} / \mathrm{m}^{3}$

$\mathrm{H}_{\mathrm{A}}$ : Mean radon concentration is less than $200 \mathrm{~Bq} / \mathrm{m}^{3}$

\section{Descriptive Statistics}

Table 2: Descriptive Statistical Analysis of the count, mean and standard deviation from a two sample $T$ test based on area.

\begin{tabular}{|c|c|c|c|}
\hline Variable & Count & Mean & $\begin{array}{c}\text { Standard } \\
\text { Deviation }\end{array}$ \\
\hline $\begin{array}{c}\text { North } \\
\text { Shore }\end{array}$ & 93 & 35.935 & 50.086 \\
\hline
\end{tabular}




\begin{tabular}{|c|l|l|l|}
\hline $\begin{array}{c}\text { Sea to } \\
\text { Sky }\end{array}$ & 41 & 38.341 & 38.341 \\
\hline
\end{tabular}

Table 3: Descriptive Statistical Analysis of the count, mean and standard deviation from a two sample $T$ test based on foundation type.

\begin{tabular}{|c|c|c|c|}
\hline Variable & Count & Mean & $\begin{array}{c}\text { Standard } \\
\text { Deviation }\end{array}$ \\
\hline $\begin{array}{c}\text { Crawl } \\
\text { Space }\end{array}$ & 24 & 23.375 & 34.891 \\
\hline $\begin{array}{c}\text { Slab on } \\
\text { Grade }\end{array}$ & 28 & 30.723 & 33.723 \\
\hline
\end{tabular}

Table 4: Descriptive Statistical Analysis of the count, mean and standard deviation from a one sample $T$ test against the Canadian guideline for the amount of radon in the home.

\begin{tabular}{|c|c|c|c|}
\hline Variable & Count & Mean & $\begin{array}{c}\text { Standard } \\
\text { Deviation }\end{array}$ \\
\hline Radon & 166 & 33.753 & 43.145 \\
Levels & & & \\
\hline
\end{tabular}

\section{Inferential Data}

NCSS Data Analysis software (NCSS) was used to conduct descriptive statistical analysis which included the count, mean and standard deviation (NCSS, 2018). Data was classified as numerical and three statistical tests were performed. A two sample $T$ test was performed twice, and a one sample $T$ test was performed once. Table 2 shows the count, mean and standard deviation of the North Shore and Sea to Sky variables by area. The second two sample $T$ test was performed based on foundation; crawl space and slab on grade (Table 3). Finally, a one sample $T$ test was conducted against the Canadian guideline of $200 \mathrm{~Bq} / \mathrm{m} 3$ for radon with all samples collection from last year's study (Table 4) (Canada. 2016).

\section{Interpretation of Results}

Table 5: Two Sample T Test of location, test \#1

\begin{tabular}{|l|l|}
\hline P Value & $P=0.242$ \\
\hline Conclusion & $\begin{array}{l}\text { Do not reject Ho and } \\
\text { conclude that there is no } \\
\text { difference between the } \\
\text { North Shore and Sea to } \\
\text { Sky corridor in terms on } \\
\text { radon concentration } \\
\text { levels inside homes. }\end{array}$ \\
\hline
\end{tabular}




\begin{tabular}{|l|l|}
\hline Since $p$ value is greater \\
than 0.05 we do not \\
reject Ho and conclude \\
that our data is not \\
significant.
\end{tabular}

Table 6: Two sample T test of basement type, test\#2

\begin{tabular}{|l|l|}
\hline P Value & $P=0.073$ \\
\hline Conclusion & $\begin{array}{l}\text { Do not reject Ho and } \\
\text { conclude that there is } \\
\text { no difference between } \\
\text { foundation type (crawl } \\
\text { space and slab on } \\
\text { grade). Since p value is } \\
\text { greater than 0.05 we do } \\
\text { not reject Ho and } \\
\text { conclude that our data } \\
\text { is not significant. }\end{array}$ \\
\hline
\end{tabular}

Table 7: One Sample T test against the standard, test \#3

\begin{tabular}{|l|l|}
\hline P Value & $P=0.00$ \\
\hline Conclusion & $\begin{array}{l}\text { Reject } \mathrm{H}_{\mathrm{O}} \text { and accept } \\
\text { the alternative } \\
\text { hypothesis that the } \\
\text { mean concentration is } \\
\text { less than } 200 \mathrm{~Bq} / \mathrm{m}^{3} . \mathrm{P} \\
\text { value is less than } 0.05 \\
\text { and therefore we } \\
\text { conclude that our }\end{array}$ \\
\hline
\end{tabular}

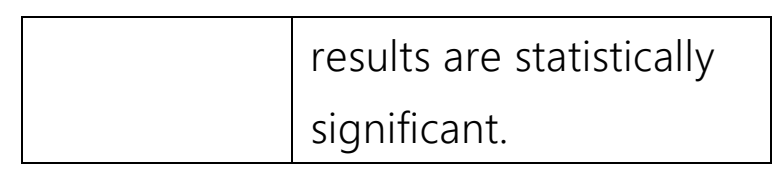

\section{DISCUSSION}

Test \#1: The first significant statistical test (two sample $T$ test) determined that radon levels in the North Shore and Sea to Sky Corridor are the same. The $P$ value (0.242) was greater than 0.05 and therefore not statically significant. This could be because the North Shore and Sea to Sky Corridor are very similar in terms of geographical location. The North Shore is composed of a mix of metamorphic rock and granitic rock while the Sea to Sky corridor (Whistler area) is composed of metamorphosed granitic rocks (CGEN Archive., 2018). The similarity in rock foundation could play a factor in the amount of natural radon in both of the areas. Since both of them are similar in ground type, it did not show reflectively during the statistical test done (two sample $\mathrm{T}$ test). Although granite and metamorphic rock in the ground have been associated with higher levels of radon, sediment used below the house could have prevented radon from entering, therefore, making the radon 
concentraions similar between both locations (Hauri, Huss, Zimmermann, Kuehni, \& Röösli, 2012; Kropat et al., 2014).

Test \#2: The second statistical test (two sample $\mathrm{T}$ test) determined that radon concentration were the same for crawl space and slab on grade foundation types. The $P$ value (0.073) was bigger than 0.05 and therefore concluded not significant. In a study done by Daoud et al., 2001 determined that when a thin film membrane was used with concrete slab foundation, was very effective at preventing radon from entering the home (figure 2). Slab on grade and crawl space foundation types were the two most popular in this study.

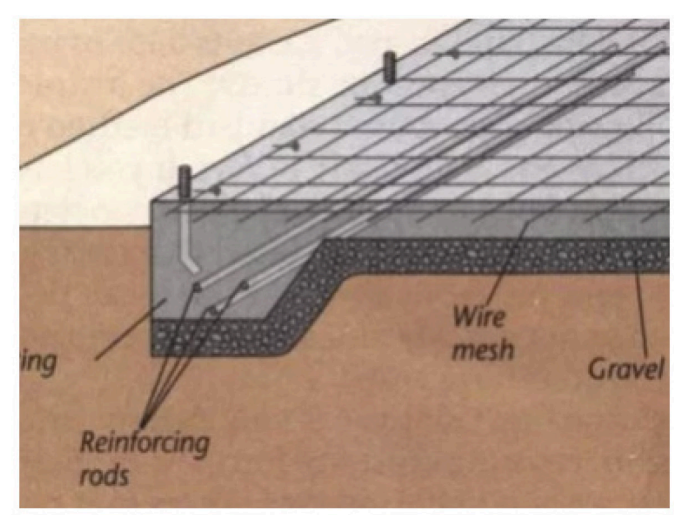

Figure 2: Image obtained from Concrete Network (2019) of slab on grade foundation.
Test \#3: Finally, a one sample t test was conducted and sound to be significant (p value less than 0.05). Our statistical test revealed that the mean radon concentration is less than $200 \mathrm{~Bq} / \mathrm{m} 3$. This is good because upper limit for radon exposure in homes is 200 Bq/m3 (Canada., 2017). Therefore, none of the houses in the areas tested were high in radon concentration. This study's aim was to see if houses in that area were high in radon. Our results showed that radon is under the limit, and therefore not considered high. Because these results are not high, it can be assumed that the people living in these houses face chronic exposure to radon. This also means that less exposure to radon is less potential to be harmed from lung cancer.

\section{KNOWLEDGE TRANSLATION}

With this knowledge about radon many things can be done with it. It can be published into a scientific article where people have free access to the information. This knowledge can also aid in policy making for building code, ensuring that certain areas need to be aware of radon gas when building homes. This research is also a good starting point 
for awareness programs. Kits can be loan out in libraries and have a chance to stay engaged with the community. This research can also be presented to smaller communities in rural areas to spark interest in radon gas in homes. Additionally, it can help raise the awareness to Canadians about radon in homes.

\section{LIMITATIONS}

There were a few limiting factors that made this project difficult to carry out. The time of this project to run is long. In order to obtain accurate results, the test kit must be placed in the home for at least three months. However, within this time period the test kits could be lost or potentially misplaced. In addition, the instructions were sometimes confusing and involved constant educational opportunities with the participants to make sure they understood how to activate and place it. Another limitation to this project was finding the participants, the ethics granted by Simon Fraser University placed certain restrictions on how we were allowed to contact people to participate in the study, this could be one of the reasons for a small sample size.
Although money was not a limitation to this project and test kits were free, it was difficult to find the correct candidate to give the test kits to. The participant needed to have a basement, some people approaching us lived in apartments, which was not the main target group for this project.

\section{FUTURE PROJECTS}

Future research that could be done from this project are:

- Making a survey to see if the population are aware of radon and the dangers of radon gas and to see if where they live affects how they think

- Testing radon levels in newer style houses compared to older styles of houses

- Determine if radon is entering the home in other ways (drinking water)

- Look at various methods of radon remediation to see which method is most popular/ most efficient

\section{CONCLUSION}


Radon gas is one of the leading causes of lung cancer. This study was set out to determine if there were high radon concentrations present in Vancouver North Shore. Our statistical results showed that radon found in the locations alliable were lower than the Canadian guideline, therefore not considered high. Further testing could be done in different areas, closer to the mountains for further research.

\section{ACKNOWLEDGEMENTS}

I would like to thank Dr. Nicol for her guidance and expertise in the project. In addition to her proposals which have granted funding for this project. Thank you Dale Chen for inciteful comments throughout the paper.

\section{COMPETING INTEREST}

The authors declare that they have no competing interest.

\section{REFERENCES}

Arvela, H., Holmgren, O., \& Reisbacka, H. (2012). Radon prevention in new construction in Finland: A nationwide sample survey in 2009. Radiation Protection Dosimetry, 148(4), 465-474. https://doi.org/10.1093/rpd/ncr192

Baeza, A., García-Paniagua, J., Guillén, J., \& Montalbán, B. (2018). Influence of architectural style on indoor radon concentration in a radon prone area: $\mathrm{A}$ case study. Science of the Total Environment, 610-611, 258-266.

https://doi.org/10.1016/j.scitotenv.2017.08 .056

Barnes, G., Fisher, B., Postma, J., Harnish, K., Butterfield, P., \& Hill, W. (2010). Incorporating environmental health into nursing practice: a case study on indoor air quality. Pediatric Nursing, 36(1), 33-9, 52; quiz 40.

Bochicchio, F., Campos-Venuti, G., Piermattei, S., Nuccetelli, C., Risica, S., Tommasino, L., ... Cappai, M. (2005). Annual average and seasonal variations of residential radon concentration for all the Italian Regions. Radiation Measurements, 40(2-6), 686-694. https://doi.org/10.1016/j.radmeas.2004.12 .023 
Bräuner, E. V., Rasmussen, T. V., \& Gunnarsen, L. (2013). Variation in residential radon levels in new Danish homes. Indoor Air, 23(4), 311-317. https://doi.org/10.1111/ina.12021

British Columbia Centeres of Disease Control (BCCDC). (2018). Radon.

Retreived from

http://www.bccdc.ca/health-info/healthyour-environment/contaminants/radon.

Canada. (2017). Guide for Radon Measurements in Residentail Dwellings (homes). Retrieved from https://www.canada.ca/en/healthcanada/services/publications/healthrisks-safety/guide-radon-measurementsresidential-dwellings.html

Canada. (2017). Radon: is it in your home? Retrieved from

https://www.canada.ca/en/healthcanada/services/environmentalworkplace-health/reportspublications/radiation/radon-yourhome-health-canada-2009.html\#a6

Canada. (2016). Radon - Reduction Guide for Canadians. Retrieved from https://www.canada.ca/en/health- canada/services/environmentalworkplace-health/reports-

publications/radiation/radon-reductionguide-canadians-health-canada2013.html

Chen, J. (2017). COMPARATIVE STUDY OF RADON EXPOSURE IN CANADIAN HOMES AND URANIUM MINES - A DISCUSSION ON THE IMPORTANCE OF NATIONAL RADON PROGRAM. Radiation Protection Dosimetry, 177(1), 83-86.

https://doi.org/10.1093/rpd/ncx132

Chen, J., Rahman, N. M., \& Atiya, I. A. (2010). Radon exhalation from building materials for decorative use. Journal of Environmental Radioactivity, 101(4), 317322.

https://doi.org/10.1016/j.jenvrad.2010.01.0 $\underline{05}$

CGEN Archive. (2018). Vancouver Rocks. Retrieved from

https://www.cgenarchive.org/vancouverrocks.html

Collignan, B., Lorkowski, C., \& Améon, R. (2012). Development of a methodology to characterize radon entry in dwellings. 
Building and Environment, 57, 176-183.

https://doi.org/10.1016/j.buildenv.2012.05. $\underline{002}$

Concrete Network. (2019). Three Types of Concrete Foundations. Retrieved from https://www.concretenetwork.com/concr ete/foundations.htm

Copes, R., \& Scott, J. (2007). Radon exposure: can we make a difference? CMAJ : Canadian Medical Association Journal, 177(10), 1229-31.

https://doi.org/10.1503/cmaj.070559

CuconDinu, A., Cosma, C., Dicu, T., Begy, R., Moldovan, M., Papp, B., ... Sainz, C. (2012). Thorough investigations on indoor radon in Băita radon-prone area (Romania). Science of the Total Environment, 431, 78-83.

https://doi.org/10.1016/j.scitotenv.2012.05 .013

Darby, S., Hill, D., Auvinen, A., BarrosDios, J. M., Baysson, H., Bochicchio, F., ... Doll, R. (2005). Radon in homes and risk of lung cancer: Collaborative analysis of individual data from 13 European casecontrol studies. British Medical Journal, 330(7485), 223-226. https://doi.org/10.1136/bmj.38308.47765 $\underline{0.63}$

Daoud, W. Z., \& Renken, K. J. (2001). Laboratory assessment of flexible thinfilm membranes as a passive barrier to radon gas diffusion. Science of the total environment, 272(1-3), 127-135.

Gooding, T. D. (2018). An analysis of radon levels in the basements of UK workplaces and review of when employers should test. Journal of Radiological Protection, 38(1), 247-261. https://doi.org/10.1088/1361-6498/aaa18c

Hauri, D. D., Huss, A., Zimmermann, F., Kuehni, C. E., \& Röösli, M. (2012). A prediction model for assessing residential radon concentration in Switzerland. Journal of Environmental Radioactivity, 112, 83-89.

https://doi.org/10.1016/j.jenvrad.2012.03.

\section{4}

Inoue, K., Hosoda, M., Tokonami, S., Ishikawa, T., \& Fukushi, M. (2013). Investigation of radon and thoron concentrations in a landmark skyscraper in Tokyo. Journal of Radioanalytical and Nuclear Chemistry, 298(3), 2009-2015. 
https://doi.org/10.1007/s10967-013-2661-

Radonova. (nd). Global Leaders in

Radon Measurement. Retrieved from

Jones, S. E., Foster, S., \& Berens, A. S.

https://radonova.com.

(2018). Radon Testing Status in Schools

by Radon Zone and School Location and Demographic Characteristics: United

States, 2014. The Journal of School

Nursing, 105984051878544.

https://doi.org/10.1177/105984051878544

1

Kropat, G., Bochud, F., Jaboyedoff, M., Laedermann, J. P., Murith, C., Palacios, M., \& Baechler, S. (2014). Major influencing factors of indoor radon concentrations in Switzerland. Journal of Environmental Radioactivity, 129, 7-22. https://doi.org/10.1016/j.jenvrad.2013.11.0 $\underline{10}$

NCSS Statistical Software. (2018). NCSS Data Analysis 12, Retrieved from https://www.ncss.com/download/ncss/u pdates/ncss-12/.

RDS Environmental. (2017). Types of Radon Test Kits. Retrieved from https://www.rdsenvironmental.com/rad on/types-radon-test-kits/.

Radon Environmental Management Corp. (2012). Mapping the geologic radon potential in Canada, Reterived from

http://www.radonaware.ca/database/files /library/British_Columbia_Radon_Potenti al_Map.pdf.

Rake Action on Radon (n.d). Radon Test Kits. Retrieved from

https://takeactiononradon.ca/test/rado n-test-kits/.

Statistics Canada.(2016). Environment Fact Sheets Radon awareness in Canada. Reterieved from https://www150.statcan.gc.ca/n1/pub/16508-x/16-508-x2016002-eng.htm.

WHO. (1988). Indoor Air Quality: Radon Report on a WHO Working. Journal of Environmental Radioactivity, 8(13), 73-91. 